International Journal of Applied Linguistics \& English Literature

ISSN 2200-3592 (Print), ISSN 2200-3452 (Online)

Vol. 1 No. 5; September 2012 [Special Issue on General Linguistics]

\title{
Engaging with Old Testament Stories: A Multimodal Social Semiotic Approach to Children Bible Illustrations
}

\author{
Abuya Eromosele John (Corresponding author) \\ Department of General Studies, Rufus Giwa Polytechnic. Owo, Ondo State, Nigeria \\ Tel: +234-08131231331 E-mail: abuyaej@yahoo.com \\ Akinkurolere Susan Olajoke \\ Department of General Studies, Rufus Giwa Polytechnic, Owo, Ondo State, Nigeria \\ Tel: +234-08032099737_E-mail: olujoke2126@yahoo.com
}

Received: 31-07- 2012

Accepted: 27-08- 2012

Published: 03-09- 2012

doi:10.7575/ijalel.v.1n.5p.219

URL: http://dx.doi.org/10.7575/ijalel.v.1n.5p.219

\begin{abstract}
Studies based on Multimodal Discourse Analysis (MDA) do not only abound but have remained on the increase in recent times. However, focus has not been on the multimodal analysis of Children Bible stories through the linguistic framework of social semiotics. This paper, informed by this need presents and analyses pictorials of Children Bible stories, thus reflecting at one level the linguistic features and how they are being complemented by visual features on another level. Also, the paper emphasizes the importance and effectiveness of visual features by revealing meanings. The study concludes that despite the fact that linguistic features could convey meaning, certain meanings are best conveyed through the use of visual images especially to children who are passive readers.
\end{abstract}

Keywords: Multimodal, Children, Social - Semiotic, Images, Bible, Discourse, Analysis

\section{Introduction}

The Bible is widely known as the most important book of the Christians. The Christianity religion is encapsulated and entrenched in the doctrines that manifest in the Bible. No doubt, the Bible is indispensable to every Christian. Christians make use of the Bible as an essential tool of evangelism. The early missionaries that came to Nigeria targeted the children, and the introduction of western education went a long way to assist them in evangelism. Most adult were already addicted to their native gods but children that usually possess flexible minds became interested in Christian religion.

Apart from the Bible, the gospel of Christian religion is spread through tract, pamphlet, poster, magazine, bulletin, handbill and more importantly Bible story books. The Bible story book is not synonymous with the Bible. Hence, it is a book of selected stories from the Bible usually with visual images for the purpose of children evangelism. This is one of the major ways through which print media has contributed significantly to the growth of Christianity through evangelism as rightly noted by Anderson (1983) that print media has continued to be a primary vehicle for the expression of Evangelistic Christianity, and printed materials with an evangelistic agenda filled a variety of niches within the publishing industry.

The Children Bible story-book is usually targeted at children, and in most cases, the story book is studied under the guide of an adult, usually parents or children evangelists. The Bible story-book is usually filled with pictures or visual images that will usually attract and arrest the attention of children since they are passive readers. Thus, the importance of visual images in Bible story book can never be over emphasized. The visual images are mostly subservient to the verbal text but possess the ability to generate meaning as the verbal text. No wonder, Messaris and Abraham (2001) opine that:

viewers may be less aware of the process of framing when it occurs visually than when it takes place through word. Consequently, visual images may have the 
International Journal of Applied Linguistics \& English Literature

ISSN 2200-3592 (Print), ISSN 2200-3452 (Online)

Vol. 1 No. 5; September 2012 [Special Issue on General Linguistics]

capacity of conveying messages that would meet with greater resistance if put in

words, but which are received more readily in visual images.

This submission emphasizes the importance of visual images in any text which is not just created but premised on the need for images. In the case of children, the visual images as Bible story illustrations are meant to make the stories of the Bible easy to understand by such representation. Hence, the children do not just read the text but also the images. On images, Kress and Leeuwen (2006) posit that:

images are produced in the context of real social institutions, in order to play
a very real role in social life-in order to do certain things to or for their
readers, and in order to communicate attitudes towards aspects of social life
and towards people who participate in them, whether authors and readers are
consciously aware of them or not.

2. Multimodal Discourse Analysis (MDA)

Synder (2009) defines multimodal discourse analysis as the study of the intersection and interdependence of various modalities of communication within a given context. More importantly, multimodal discourse analysis is an emerging field of discourse which studies languages together with other semiotic resources for the purpose of deriving meaning in a social context. The principle that underpins multimodal analysis posits that communication takes place across different modes. Mode refers to the distinct semiotic system for expressing meaning.

There are two approaches to multimodal interactional analysis: Norris approach, and Baldry and Thibaults approach. Norris' approach bothers on what individuals express and react to in specific situations which the ongoing interaction is always constructed (Norris 2004). Through the work of Norris, a clear distinction is made between embodied and semibodied modes of communication. Baldry and Thibault's approach is premised on the Halliday notion of text as 'living language' by observing that different semiotic modalities make different meanings in different ways according to the different media of expression they use. Baldry and Thibault approach enables the examination of the relationship between multimodal text and genre.

Researchers in the field of MDA are concerned with the role of mode on meaning as Norris (2004) defines mode as a loose concept of a grouping of signs that have acquired meaning in our historical development. Analyses that bother on modality focus on the effect of form on the consciousness of hearers, speakers or readers (Keane 1997). Infact, it is the introduction of multimodality that brought emphasis on image, music, gesture, and so on. No wonder, Linda (2005) states that modality refers to the relationship of messages or how true an image is as rightly opined by Kress and Van Leeuwen (1996).

\section{Social Semiotic Approach to Multimodal Discourse Analysis (MDA)}

Multimodality has its root in Social Linguistics and Discourse Analysis, and it has undergone various transformations especially from mid 1980s, whereby scholars begin to focus on making meanings beyond languages. The social semiotic approach is concerned with the way people use semiotic resources both to produce communicative artefacts and events and to interprete them ... in the context of specific social situations and practice (Van Leeuwen 2005). The theoretical foundation of social semiotic approach to multimodal discourse analysis is derived from Systemic Functional Linguistic (SFL) view of language as a social semiotic (Halliday 1978). It is along this reasoning that Halliday 1978 defines semiotic as a process of making meanings by selecting 'from the total set of options that constitute what can be meant'.

According to Olowu (2012):

Kress and Van Leeuwen's contribution to the field of semiotic lies in their recognition of visual language as an underrated of communication which up till now has been subordinate to verbal language. They suggest that as technology facilities, the sharing of visual information, a way and means of understanding visual communication is more important than ever.

This argument stresses the fact that visual information is the focus in the social semiotics. The social context of such form determines meaning accrued to it. No wonder, Thibault (1991) submits that:

In social semiotics, the basic logic is that of contextualization. No semiotic form, material entity or event, text, or action has meaning in and of itself. The meaning these have are in and through the social meaning - making practices which 
International Journal of Applied Linguistics \& English Literature

ISSN 2200-3592 (Print), ISSN 2200-3452 (Online)

Vol. 1 No. 5; September 2012 [Special Issue on General Linguistics]

construct semiotic relations among forms, material processes and entities and

social actions

Since, it is now impossible to make sense of texts even of their linguistic parts alone, without having a clear idea of what these other features might be contributing to the meaning of a text (Kress 2000), the social semiotic approach of Kress and Van Leeuwen (2001) is based on Halliday (1978)'s three fundamental metafuntions: The ideational metafuntion, the interpersonal metafuntion, and the textual metafuntion. These metafuntions operate in the semantic of every language and are defined as:

i. The ideational metafuntion:- This refers to the resource for the representation of experience: our experience of the world that lies about us and also inside us, the world of our imagination. It is meaning in the sense of content.

ii. The interpersonal metafuntion:- This is the resource for meaning as a form of action. The speaker or writer doing something to the listener or reader by means of language.

iii. The textual metafuntion:- This is the resource for maintaining relevance to the context both the preceding and following text and context of the situation

\section{Objectives of the study}

The objectives of the study are outlined below:

i. Examine the linguistic features of the selected Bible stories illustrations

ii. Analyse the ways visual information is presented in the Bible stories illustration

iii. Observe and describe the relationship between the linguistic and the visual components in developing themes associated with the illustrations

\section{Research Methodology}

For the purpose of this study, illustrations of Children Bible stories are selected. The Children Bible Story Book is titled 101 favorite stories from the Bible by Ura Miller (2006). The Book typifies a true Children Bible Story Book with a visual illustration accompanying each story. The choice of the book is premised on its richness in the use of colour and visual images. Four illustrations are selected from Old Testament stories; this choice is premised on the fact that most concepts and objects in olden days are usually difficult to be explained in linguistic form to the modern day children without recourse to modes that can make such real. The analysis of selected illustrations will be anchored on the themes of family and love. The analysis will be done using Kress and Van Leeuwen's Multimodal Discourse Analysis through Social Semiotic Approach. The selected illustrations are labeled A- D.

\section{Data presentation and Discussion of Themes}

This section is on data presentation and discussion. As earlier mentioned, each selected story illustration will be analysed and discussed in close reference to the relevant and appropriate themes.

\section{Illustration $A$}

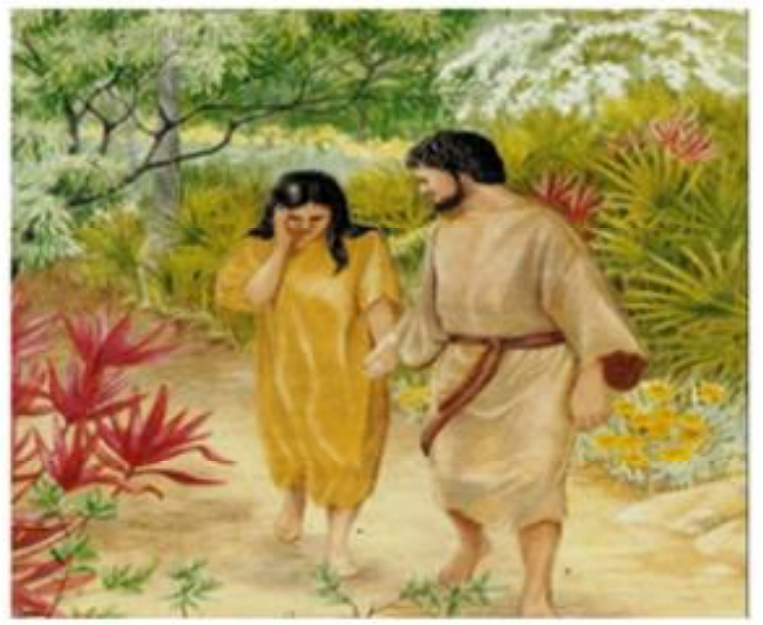

\section{Illustration B}

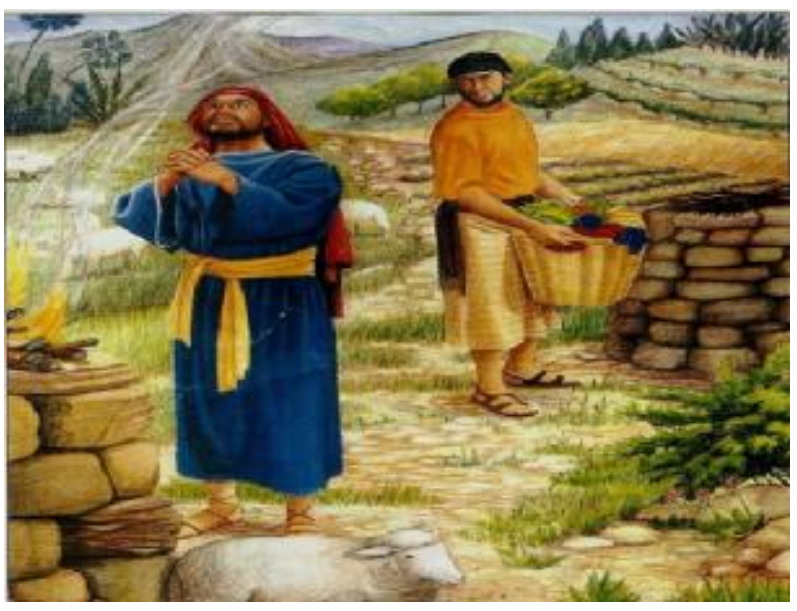

Verbal Anchorage A: Adam and Eve sent out of the garden because of disobedience. 
International Journal of Applied Linguistics \& English Literature

ISSN 2200-3592 (Print), ISSN 2200-3452 (Online)

Vol. 1 No. 5; September 2012 [Special Issue on General Linguistics]

The title of the story is "The First Sin 'Cast out of the Garden of Eden". There are lexical items employed in the process of narrating the story which can be found in Genesis 3, such lexical items are: garden, beautiful, station, husband, wife, God, tempt, home, serpent, animal, disobedience, Adam, Eve, voice, command. These linguistic features serve as a mode through which the story of Adam and Eve's experience in the Garden of Eden was narrated. The story is significant for it enables the children to know and understand the beginning of family since they are product of family. The story of Adam and Eve explicates the origin of family. The words associated with the family in the linguistic mode are 'husband, wife, and home'. It is in the home that we find husband and wife as marriage in Christianity is regarded as a union between a man and a woman in such that they become husband and wife (Olowu 2012).

6.1 Visual Component of $A$

Kress and Van Leeuwen (2001) posit that colour is 'entirely different from language'. In the illustration, the garden is presented with green colour with other colours such as yellow, pink, and white; they are employed to illustrate flowers. This shows riches of the Garden of Eden. The children become aware of the fact that Garden of Eden is rich in fruits. The colours as signifiers serve as a mode.

The picture of Adam and Eve signifies husband and wife. They are being represented in a way that Adam takes the lead out of the garden, and Eve's head is bent with her hand raised to support her cheek. It signifies sobriety as a result of her disobedience to God's instruction by giving the husband fruit from the forbidden tree even though she was deceived by the serpent. The picture represents the reward of sin for the caption reflects the exit of Adam and Eve from the beautiful Garden of Eden. The fact that Adam holds the hand of Eve despite their predicament shows the love that serves as the bond in family. The covenant between husband and wife is 'for better for worse' and 'till death parts them', this is demonstrated through Adam's action.

6.2 Verbal Anchorage B: Cain and Abel each offer a gift upon altar

The title of the story is 'Cain Kills His Brother Abel 'The First Family'. Words identified from the story are 'baby, child, gift, stone, killed, murderer, altar, prayed, God, sin, angry, worship, brother'. The use of 'baby' 'child', 'brother' in the story depicts family. Every society is made up of a number of units- the unit is family. The author narrates how Cain killed his brother (Abel) as a result of anger that grew out of jealousy because his offering displeased God while Abel's offering was accepted according to Genesis 4.

\subsection{Visual Components of Illustration B}

The visual illustration is colourful. Abel is wearing a blue cloth, blue represents love while Cain cloth is brown, other colours are: green for vegetation, yellow for flame of fire, grey for smoke, and white for lamb. The location or position of Cain and Abel is in opposite direction. Abel's face is lifted up which depicts that he is looking unto God while Cain is looking towards his brother direction and he is not concentrating on his sacrifice. Any time, human being focuses on men rather than God, it usually leads to jealousy, rivalry, bitterness, anger and even murder. The smoke from Abel's sacrifice represents acceptance. Hence, his hands are brought together to show gratitude to God. The illustration represents a typical row among siblings which can generate into sin such as anger or murder, and develops the theme of family further by emphasizing that love is an essential ingredient in the family. Assuming he loved Abel, he would not have killed him.

\section{Illustration C}

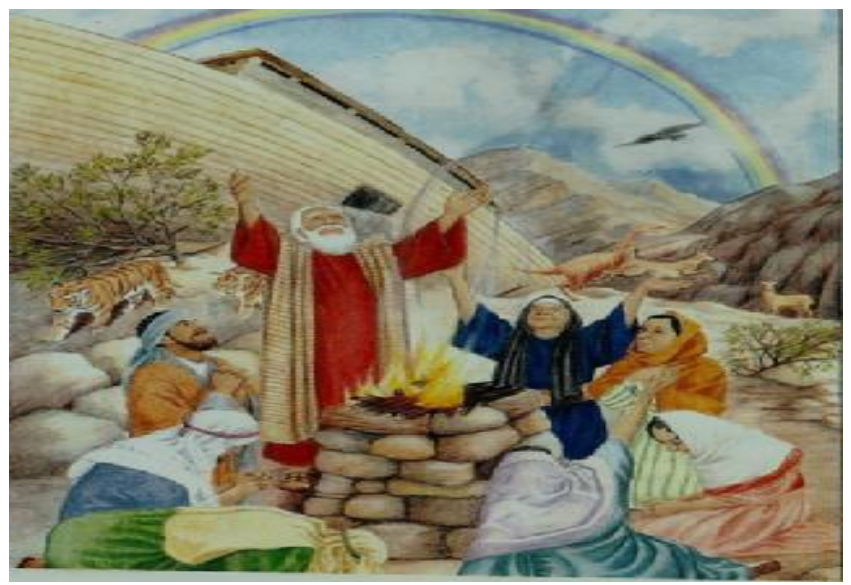

Verbal Anchorage: Noah and his family thank God for saving their lives 
International Journal of Applied Linguistics \& English Literature

ISSN 2200-3592 (Print), ISSN 2200-3452 (Online)

Vol. 1 No. 5; September 2012 [Special Issue on General Linguistics]

The story is titled 'Noah - The Ark Builder History's First Boat Ride'. There are lexical items such as people, earth, Noah, God, ark, family, animals, birds, rain, door, thankful, saving, altar, rainbow, sky, flood and others. The author narrates how God destroyed people from the earth as a result of their wickedness while Noah and his family were saved. The author concludes that God formed a beautiful rainbow in the sky as a sign of His promise never to destroy the earth with a flood again. It is a matter of high significance that those that survived the flood belong to the same family. This further places prominence on the institution of family.

\subsection{Visual component of illustration C}

The illustration is made up people wearing clothes of colours such as red, blue, green, orange, yellow e.t.c. The ark has faded-brown colour while the rainbow has seven different colours. Noah is seen wearing red cloth that represents danger since he led his family and other non- human creatures through a dangerous adventure. The smoke is grey while the flame is yellowish on a light brown altar. Noah and his family members' posture in the illustration as they offer sacrifice of thanksgiving depicts that they give glory to God. The fact that Noah is standing while others are kneeling or sitting down portrays him as the leader as well as the head of the family. Also the rainbow seven colour represents perfection. Hence, the rainbow is not just a sign but a signifier of the promise of God to the people.

The bond that ties the members of the family together is love for they surround the altar, it is love that brings about togetherness in a family. The appearance of the animals such as lion, antelope, e.t.c in the illustration shows that other creatures (animal and birds) survive the flood disaster because they entered the ark of Noah. The Ark is synonymous to the present day Jesus Christ in christian faith. It is believed that anyone that does not accept Jesus Christ as his personal Lord and Savior will not be saved according to John 3:16- 18 .

\section{Illustration D}

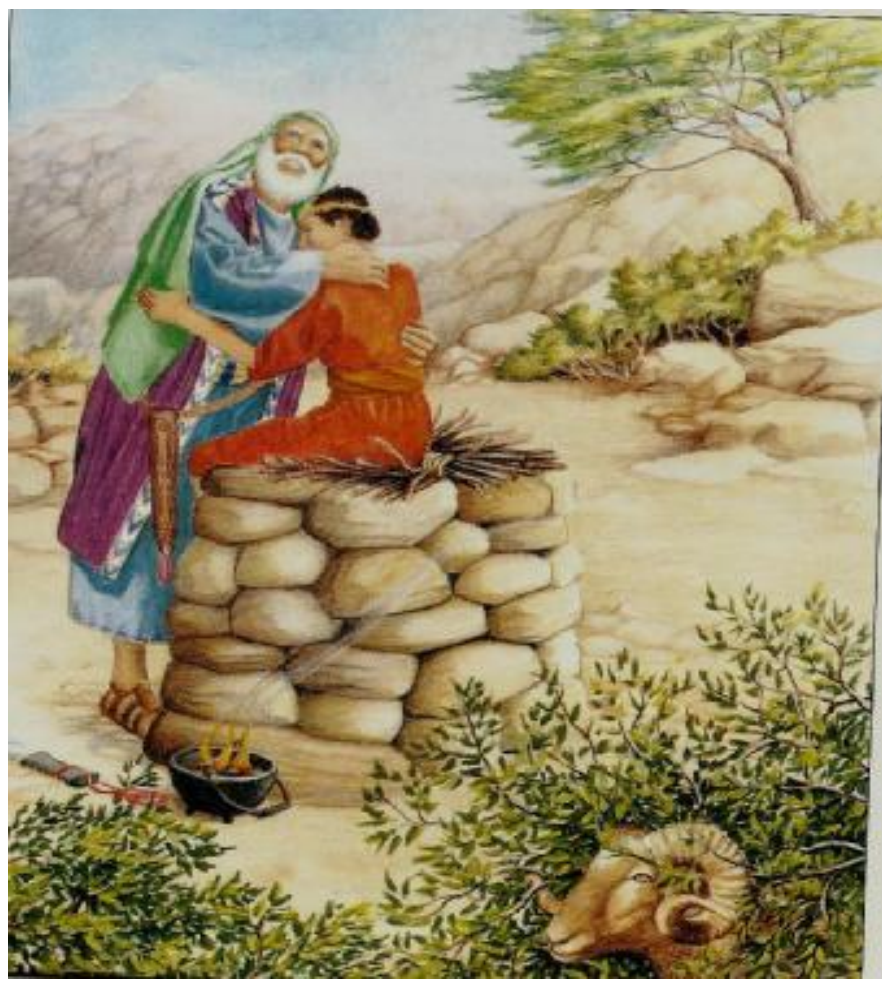

Verbal Anchorage: Abraham is thankful that he does not have to offer his son.

The above illustration accompanies a story, titled 'Abraham Sacrifice- A Great Test of Love'. In the story, certain words such as father, children, land, altar, worship, knife, kill, son, multitude, people, angel, ram, bushes, thankful and the likes were employed by the author to narrate the story of how Abraham obeyed God by offering his only son as a sacrifice to God. The unit of family is not usually regarded as complete without child/children especially in African culture. Hence, the importance of a child in marriage can never be over emphasized.

Despite the pain and rigours that Abraham and Sarah went through before the birth of Isaac in their old age, he willingly submitted Isaac for sacrifice (Genesis 15:1- 6; 21;22). The author concludes the story on how God intervened by providing a ram instead of Abraham's son at the point of sacrifice. 
International Journal of Applied Linguistics \& English Literature

ISSN 2200-3592 (Print), ISSN 2200-3452 (Online)

Vol. 1 No. 5; September 2012 [Special Issue on General Linguistics]

6.5 Visual Components of Illustration D

Isaac (Abraham son) is seen wearing a red cloth which signifies danger. The red cloth is usually associated with occultism or rituals. The body is the sacrifice to be offered to God.

The knife meant to kill the boy is also tied with red string, this also is synonymous to the meaning derived from the red colour cloth. Abraham wears a multicolor cloth in the illustration. The colours are purple, green and blue. The blue colour depicts love. This represents the love that Abraham had for God. Anywhere there is altar, there will be sacrifice, and the boy is placed on the altar as it becomes a true signifier of Abraham's submission to the will of God.

The ram is found beneath the bushes while pot of fire is black in colour which represents death. The image of the ram beneath bushes shows that it is an unexpected and sudden provision. Here the visual image speaks more than the text as it is observed that the visual image may be more effective than linguistic text in the "construction of affective meaning' ( Olowu 2012).

\section{Conclusion}

The visual image presented in our analysis and discussions are very powerful. The four illustrations are rich in meaning. It is observed that certain images signify certain phenomena in the present day. The image of altar in illustration B- D represents the place of prayer. In the Old Testament Christian religion, altars were usually erected by assembling stones, also sacrifices were provided for burnt offerings.

Children understand Bible stories better through illustrations. More so, in the present Christian practice, sacrifices are no more burnt in the churches or on altars. Hence, there is no better way to bring to fore the meaning that an altar in the Old Testament Christian practice connotes other than employing images. Postures, position, gaze, and distance are significant for meaning in the selected illustrations (Busa 2010). Therefore, images are read just as linguistic texts are read. In teaching children, parents or teachers are supposed to be conscious and conversant with the level and qualities that children possess which should make them teach the children in the simplest manner possible. Consequently, the illustrations in the Bible stories analyzed through social semiotic approach to multimodal discourse analysis serves as a substantiating evidence.

The illustrations could also be referred to as image communication that foregrounds the linguistic features of the Bible stories in such a way that the children understanding are increased. Hence, this paper has analyzed visual information contribution towards meaning through MDA.

O'Halloran (2011) observes that one of the major challenges facing multimodal discourse analysis include the development of theories and frame work for semiotic resources other than language, the modeling of social semiotic process (in particular, intersemiosis and resemioticisation) and the interpretation of the complex semantic space which unfolds within and across multimodal phenomena. It is expected that theories that bother specifically on semiotic resources will make a better contribution to multimodal analysis.

We therefore submit that a social semiotic approach to MDA should also be employed in analysing illustrations from New Testament Bible stories or better still a comparative analysis of Old and New Testament Bible stories.

\section{References}

Anderson, A. (2004). An introduction to pentecostalism: Global characteristic christianity. Cambridge: Cambridge university press.

Busa, M.G (2010). Sounding natural: Improving oral presentation skills. Language value, 2 (1), 61.

Halliday M.A.K (1978) Language as social semiotic: The social interpretation of language and meaning. London: Edward Arnold. 16.

Keane, W. (1997). Religions language. Annual Review of Anthropology. 26,47-71.

Kress, G. (2000) Challenges to thinking about language. TESOL Quarterly, 34 (2), 337-340.

Kress, G., \& Van Leeuwen, T. (1996). Reading images: The grammar of visual design. (1st Ed). London and New York: Routledge. 159

Kress,G and T. Van L. (2001). Multimodal discourse: The modes and media of contemporary communications. London: Arnold. 27

Kress, G., \& Van Leeuwen, T. (2006). Reading images: The grammar of visual design (2nd Ed). London and New York: Routledge. 15

Linda, M.M. (2005). Multimodal discourse analysis of advertisements of hongkong charity organisations. The University of Hongkong. An unpublished M.A Thesis. 
International Journal of Applied Linguistics \& English Literature

ISSN 2200-3592 (Print), ISSN 2200-3452 (Online)

Vol. 1 No. 5; September 2012 [Special Issue on General Linguistics]

Messaris, A., \& Abraham, A. (2001). The role of images in framing news stories. In Reese S. D. et al (eds)

Framing public life: Prospective on media and our understanding of the social world. London: Lawrence Erlbaun Associate $215-226$.

Miller, U. (2006). 101 favourite stories from the Bible. Ohio, USA: Christain Aid Ministries.

Norris S. (2004). Analysing multimodal interaction: A methodological framework. NewYork/London: Routledge.

O’Halloran, K.L (2011). Multimodal discourse analysis. Hyland, K. and B Partridge (eds) Companion to discourse .London/New York: Continuum.

Olowu, A. (2012). A multimodal discourse analysis of Christian women mirror magazine Obafemi Awolowo University An Unpublished M.A Thesis. 33- 43.

Synder, J. (2009). Applying multimodal discourse analysis to study image - enabled communication. School of Information Studies, Syracuse University.

The Holy Bible King James Version

Van, L. (2005). Introducing social semiotics. New York: Routledge. 